\title{
Climate Variability and Rural Livelihood Security: Impacts and Implications
}

\author{
Kehinde Olayinka Popoola, Anne Jerneck, and \\ Sunday Adesola Ajayi
}

\section{Contents}

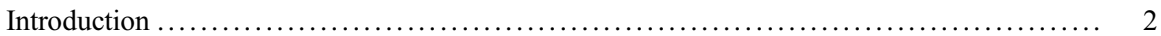

Multistage Selection of Ecological Zones and the Aged ........................... 4

Ageds' Experience of Climate Variability Impact on Their Livelihood Security ........... 5

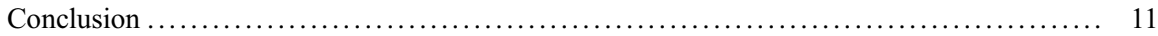

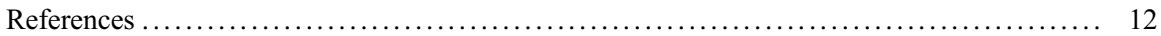

\section{Abstract}

In a typical Nigerian village, the majority of the population comprises old people who are mostly economically unproductive due to reduced or loss of physical strength brought about by ageing and ill health. Many of these rural old people still work, and do so outside the formal sector, and are particularly susceptible to the effects of climate variability and change. Few studies have reported on climate change and the rural aged and there is a research gap as regards rural elderly peoples' perception of climate variability impact on them. Since little is known

This chapter was previously published non-open access with exclusive rights reserved by the Publisher. It has been changed retrospectively to open access under a CC BY 4.0 license and the copyright holder is "The Author(s)". For further details, please see the license information at the end of the chapter.

K. O. Popoola $(\bowtie)$

Department of Urban and Regional Planning, Obafemi Awolowo University, Ile-Ife, Nigeria

A. Jerneck

Lund University Centre for Sustainability Studies, Lund, Sweden

e-mail: anne.jerneck@LUCSUS.lu.se

S. A. Ajayi

Department of Crop Production \& Protection, Obafemi Awolowo University, Ile-Ife, Nigeria

Institute for Sustainable Development, First Technical University, Ibadan, Nigeria

e-mail: sajayi@oauife.edu.ng 
about their perception of climate variability impacts and implications on the rural aged especially in relation to their livelihood activities in Sub-Saharan Africa, this chapter therefore examined the impact of climate variability on the livelihood security of the rural aged in different ecological zones of Nigeria.

Both qualitative and quantitative methods were used for data collection. Qualitative data were obtained through interviews with four aged and four aged women selected purposively in each rural community and analyzed using Content Analysis Method. Quantitative data were obtained through structured questionnaire administered to an aged male and an aged female population available in selected houses (the aged are people 60 years and over in age) in selected rural communities in selected ecological zones of Nigeria. Where there was no combination of the two (aged men and aged women), either of the two was also sufficient.

It was discovered that the ageds' experiences of climate variability impact relate to the prevailing climate variability characteristic of each ecological zones. The impact on their livelihood in these zones is seen in terms of livestock death, lack of pastures for herds, scarcity of water, pest invasion, delayed planting crop failure, need for irrigation, water logging, drowning of small animals, human and animal illness. This means that planning decisions related to climate change issues should take cognizance of the views of the aged populations especially of those residing in rural areas as they are the most affected by the impact.

\section{Keywords}

Climate variability $\cdot$ Rural aged $\cdot$ Livelihood security $\cdot$ Ecological zones

\section{Introduction}

Climate change implies a shift in the main state of a climate or in its variability, persisting for an extended period that can be decades or longer (Intergovernmental Panel on Climate Change 2007). It has been known for a while to have major global environmental, social, and economic impact (Scholze et al. 2006; Douglas et al. 2008) and poses a major serious threat to sustainable development with adverse effects on the environment, human health, food security, economic activities, natural resource management, and physical infrastructure (Government of Kenya (GOK) 2010). Climate change poses serious risks to society because of the physical characteristics of the planet, the biological resources on which human lives depend, and current social systems that are adapted to existing rather than changing climate conditions (Higgins 2014).

Climate change is rapidly emerging as one of the most serious global problems affecting many sectors in the world especially livelihood. Negative consequences in Africa are already prevalent in terms of frequent floods, droughts, and shift in marginal agricultural systems (Collier et al. 2008). Deschenes and Greenstone (2012) explained that climate change affects the two most important direct 
agricultural production inputs, precipitation, and temperature, which in turn affects livelihood. Studies have shown that Africa is getting more vulnerable to climate change/variability impact on livelihood compared to other parts of the World. This is because the livelihoods for $80 \%$ of the African population are dependent on rain-fed agriculture which are vulnerable to multiple stresses such as climate change (World Bank 2008). Countries in sub-Saharan Africa may likely suffer most from these consequences because of their greater reliance on climate-sensitive resources like agriculture for sustenance of livelihoods (Eboh 2009).

In Nigeria, about $60 \%$ of the populations are rural residents depending on agriculture for their livelihood (Central Bank of Nigeria 2006) and studies have confirmed serious effects of climate change on this population. Their vulnerability to climate change impacts is largely due to the socioeconomic and political context (Thornton et al. 2014). However, all households within a community are not equally vulnerable to climate change impact (Adger 2003). This is because vulnerability is highly differentiated (O'Brien et al. 2007) and varies across: age, gender, income, and type of livelihood. In Nigeria, women, children, and the elderly will be most vulnerable to climate change impact, especially the rural elderly who are economically less productive due to physical weakness brought about by ageing and ill health (Anele 2012).

Mcleman and Hunter (2010) explained that climate change events, impacts on livelihood and vulnerability differ considerably across geographic and ecological regions. This is because livelihoods are ecologically dependent and some regions and activities are more sensitive to climate change than others (Saarinen et al. 2012). It is therefore relevant to consider ecological characteristics in relation to climate change impacts on livelihood. Also in Sub-Saharan Africa, extreme droughts is already constraining production of food and rearing of livestock (Kebede et al. 2011). For 2050, it is projected that, especially in West Africa, yields could drop by $20-50 \%$ due to variability of rainfall reducing length of the growing season (Sarr 2012). There are many studies on climate change/variability and livelihood (Ofoegbu et al. 2017; Ubisi et al. 2017; Aniah et al. 2016; Egbe et al. 2014; Okonkwo et al. 2015; Zeleke and Aberra 2014). For instance, Aniah (2016) examined the effects of climate change on livelihoods of smallholder farmers in the Upper East Region of Ghana. The results revealed that droughts, floods, pest and diseases, postharvest losses, declining crop yields, and animal production have threatened smallholder farmers' livelihood activities. Also, Ubisi et al. (2017) investigated the perceived effects of climate change on crop production and household livelihoods of smallholder farmers in Mopani and Vhembe district, South Africa. Their study showed that subsistence farmers perceived prolonged droughts as an impact of climate change leading to low crop yield and high crop failure. These studies focused on the impact of climate change/variability on livelihood activities but the impacts on the livelihood activities of the aged were not considered. Against this backdrop, we have reason to believe that climate change impact on livelihood among the rural aged is likely to vary with geographic location and livelihood activities. Based on Nigeria as a case, this chapter provides answers to this question: How does the perceived climate variability affect rural livelihood activities of the aged population in selected rural communities of the different ecological zones of Nigeria? 


\section{Multistage Selection of Ecological Zones and the Aged}

Nigeria, situated in West Africa on Latitudes $4^{\circ} 0$ to $14^{\circ} 0^{\prime}$ North and Longitudes $2^{\circ} 2^{\prime}$ and $14^{\circ} 30^{\prime}$ East, is bounded in the west by the Republic of Benin, in the East by Chad and Cameroon, in the North by Niger Republic, in the South by Gulf of Guinea, and in the North-East by Lake Chad (Map 1). Nigeria is a multiethnic and culturally diverse society divided into 36 autonomous states (World Bank Group 2017). Nigeria has two seasons, the dry and the rainy season, and six ecological zones: Mangrove zone, Forest zone, Montane zone, Guinea savannah zone, Sudan savannah zone, and Sahel savannah zone. This chapter is set in four ecological zones with one state representing each zone-Guinea savannah zone of Oyo State (Oyo State), Mangrove zone of Ondo State (Ondo State), Sudan savannah zone (Kebbi State), and Montane zone (Plateau State) (see Map 1).

In the initial stage, the ecological zones (They are: Mangrove zone, Rain forest, Montane region, Guinea savannah, Sudan savannah and Sahel Savannah) were identified based on Keay (1949), Kueppers (1998) classification. Four Ecological Zones were randomly selected out of the six zones. They are: Guinea savannah zone, Mangrove zone, Montane zone, and the Sudan savannah zone. One State was then selected from each of the selected ecological zones. The states are Oyo State in the Guinea savannah zone (Guinea savannah zone of Oyo State), Ondo State in Mangrove zone (Mangrove zone of Ondo State), Plateau State in Montane zone, and

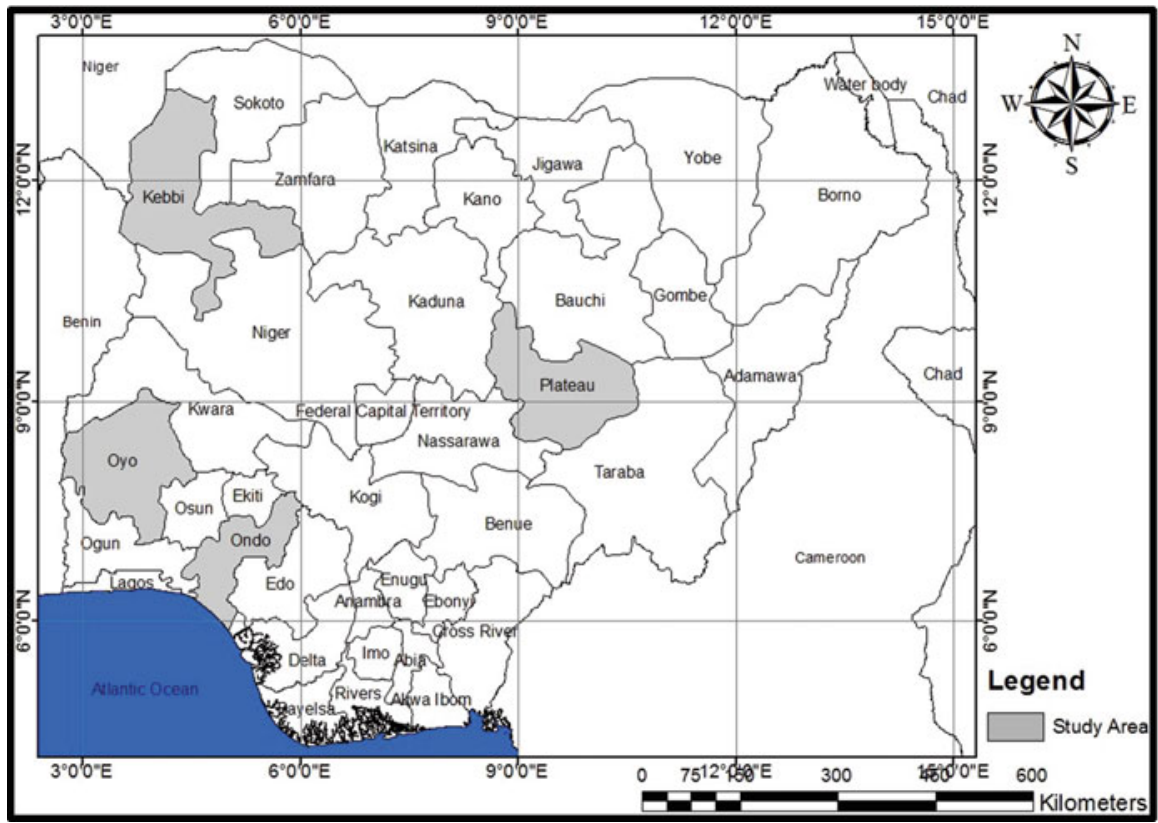

Map 1 Map of Nigeria showing the selected states. (Source: Adopted from Popoola and Ajayi 2019) 
Kebbi State in the Sudan savannah zone. In the next stage, two local government areas were selected from each of the States based on their rurality and climate change impact. The local government areas are: Ilaje and Eseodo in Ondo State; Oorelope and Atisbo in Oyo State; Riyom and Kanke in Plateau State; Jega and Yauri in Kebbi State. In the third stage, three rural settlements were selected from each of the local government areas through a simple random selection process. They are: (Ilepete, Obenla, Ebijimi) in Ilaje LGA; (Igbalekagbo, Uropati, Olorunpupa) in Ese-odo LGA; (Alaguntan, ologundudu, Sooro)in Oorelope LGA; (Alakuko, Sabe, Yowere) in AtisboLGA; (Ambob, Tahoss, Kwakwi) in Riyom LGA; (Tse, Jinglay, Lebwit) in Kanke LGA; (Akalawa, Duduke, Gindi) in Jega LGA; (Unguwar Kurya, Zara Bimi, Giwa Tazo) in Yauri LGA. To ensure a fair draw for all settlements each settlement in the respective local government area was assigned a number written on a piece of paper, placed in a container, and then drawn from the container without replacement. In the fourth stage, snowball approach was used to identify the houses where the rural aged resides. The aged were defined as people who are at least 60 years of Age.

Both qualitative and quantitative data were used (Primary Data Source). The quantitative data were obtained through structured questionnaire administered to an aged male and an aged female available in the selected houses in the selected rural communities of the selected ecological zones. Where there were no combinations of the two (aged men and aged women), either of the two was also sufficient. The qualitative data includes observations, key informant interviews, and open as well as semi-structured interviews with four aged men and four aged women selected purposively in each of the selected villages. The interviewer used progressive focusing to ask the participants both new and follow up questions. Detailed field notes and audio recording were made throughout the field observations. Data collected was disaggregated by gender to recognize the different experiences of male and female and analyzed using various methods such as descriptive statistics (frequencies and percentages) and SPSS. In the qualitative analysis, Content Analysis Method was used to identify commonalities in terms of recurring aspects and themes as well as differences and contradictions in terms of deviating views and outliers.

\section{Ageds' Experience of Climate Variability Impact on Their Livelihood Security}

In this section findings of climate variability impact on livelihood security of the rural aged in selected ecological zones of Nigeria was presented. In focus, the following domains: agriculture and food security; environment; energy; and water resources; as well as human and animal health; dwellings, transport, and migration were placed. According to Ashwill et al. (2011), climate change impact refers to the social and environmental consequences in terms of water scarcity, loss in agricultural yields, and drops in livestock production, to mention a few. It is important to examine the climate variability impact on livelihood security of the people because it helps informing and tailoring directions for adaptation (Mendelsohn 2008). It is 
also important to examine the impact on livelihood by gender and geographical locations. Examining the impact by gender helps to understand that the different roles, resources, opportunities, and agency of men and women influence how they experience, perceive, and respond locally to climate change (Ashwill et al. 2011). Vulnerability to climate change impact is highly correlated with its geographical peculiarities (Callo-Concha et al. 2013). Therefore, examining the impact by geographical location helps to determine both the perceived need to adapt and the acceptability of particular adaptive measures because of factors such as: attachment to place, cultural values, social identity, and regional risk attitudes (Adger et al. 2009).

Figure 1 shows the climate variability impact on livelihood security of the rural aged in selected ecological zones of Nigeria. Findings revealed that climate variability has affected the livelihood of the aged to a great extent. For instance, from the table, in Guinea Savannah Zone, $68.3 \%$ of the men and $69 \%$ of the women complained of water shortage and $60 \%$ men and $49.2 \%$ women felt the need for irrigation. Also, $42.4 \%$ men and $26.2 \%$ had to delay their planting; $94.6 \%$ of the men and $91.8 \%$ of the women lamented about crop failure; $37 \%$ of the men and $35.9 \%$ of the women worried about their animals getting weak and sick while $32.6 \%$ men and $27.9 \%$ women had their livestock dead. All these can be attributed to climate variability impact. Below, selected comments from aged men and women sharing their experience of climate variability impact on their livelihood security in the different selected villages of Oorelope and Atisbo Local Government Areas of Oyo State, Guninea Savannah Region of Nigeria were included.

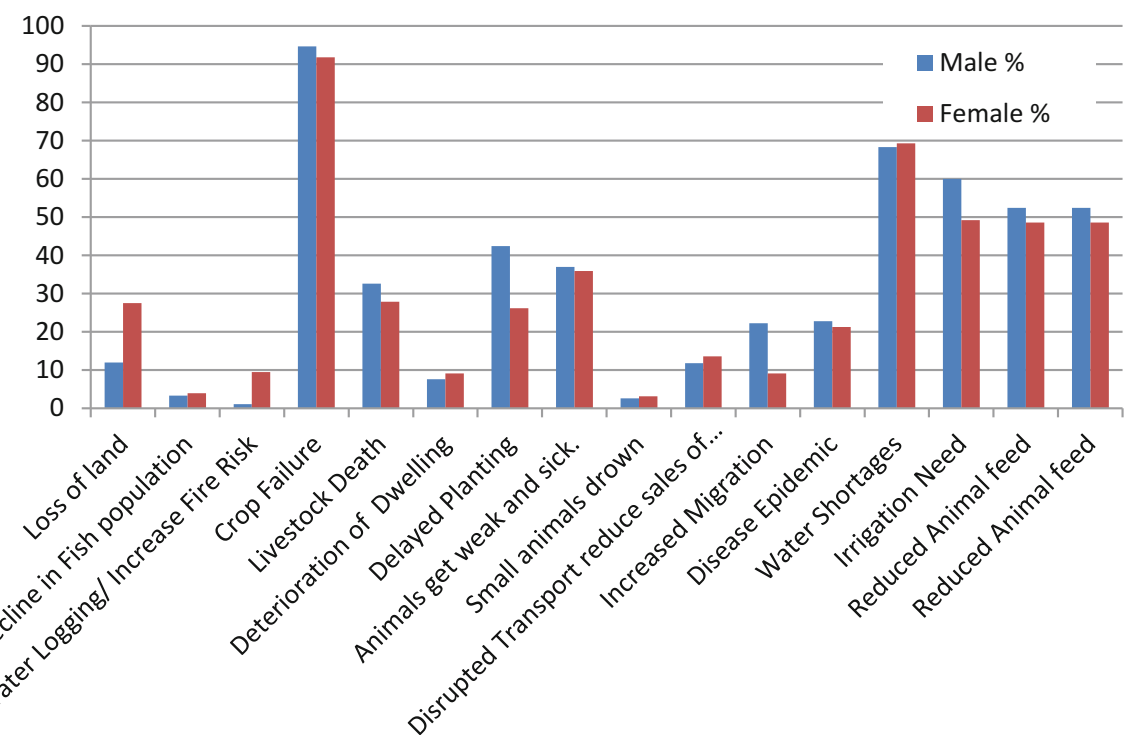

Fig. 1 Climate variability impact of livelihood security of aged men and women in Guinea Savannah Region of Nigeria. (Source: Author's Fieldwork) 
Before the change in weather, we planted maize twice a year. But now, we plant it only once. If we try to plant the second time, which is usually done in the eight month, the produce will be very small and not profitable. Just like the one I am holding now (respondent holding a sample maize), who will buy this from us? (Waliu Hamuzat, Male, 64 years)

Our yam produce is not as big as before again. The presence of yam leaf is a positive sign of a possible bountiful harvest. During the 10th and 11th month of plantation, some cultivated yams will still have their leaves intact, like before, but now, in the 9th month, some yams would have lost their leaves. Infact, the period when tubers had begun to grow proper, that is when we usually experience the lack of rain (drought). And it is usually when the yam needs the rain the most. Most importantly, these are the periods we usually have constant rainfall before. Now the story is different.

Take for example, if I planted about 3000 yam and I was only able to harvest 100 . This can only be related to the heat generated from the dry land and I cannot be at peace with such result (Kazeem Lawal, Male, 65 years)

There is shortage of food and water, and our cows are going seriously hungry. This has led to a clash between farmers and the Fulani herdsmen because the cows now go to feed on people's farmland. Any cow caught on a farmland, automatically belongs to the farmland owner. In addition, a lot of cows cannot even stand up on their own again due to hunger. The herdsmen at times usually help them up (Yussuf Dammani, Male, 62 years)

Fever most especially, and several other ailment usually surface at this period. Since food is what our body needs most, a shortage of it will lead to sickness in the body (Durodola Lamina, Female, 73 years)

The little rain we had was more of heavy storm than water. The storm was too much; in fact the structure we erected as mosque was totally destroyed by the storm. It also destroyed a lot of buildings. The storm is a new experience in this area (Ajao Abebi, Female, 68 years)

Figure 2 also shows the climate variability impact on livelihood security of the aged men and women in the Coastal Zone of Nigeria. The table indicated that $81.8 \%$ of the men and $72.5 \%$ of the women complained about decline in fish species and populations. This is because in a small-scale fishing community, many households are involved in fishery-related livelihood activities such as fishing, postharvest fish processing, fish trading, making and mending of fishing materials (OECD 2001). Therefore, decline in fish species and populations will affect their means of livelihood. Also $79.2 \%$ of the aged men and $42.9 \%$ of aged women in the area complained about water logging and 59\% men and $40.6 \%$ women had their small animals drown in the water. Moreover, $69.7 \%$ men and $40.9 \%$ lamented and worried about the deterioration of their dwellings because of heavy rainfall and flood. In most rural coastal communities of Nigeria, many dwellings are built on piles and raft foundations. These houses easily deteriorate during harsh weather conditions and thus affect the habitability of the aged in the region.

However, in some instances climate variability has some positive impacts on livelihood of rural coastal communities. For instance, one of the positive effects of flooding in the rural coastal communities is the increase in fish catch, especially during ocean flooding (Fabiyi and Oloukoi 2013). The study revealed that the Atlantic brings large fish to the continental shelf and some large fish are even found in the creeks during extensive flooding. Therefore, climate variability impact is not necessarily negative but can also be positive. Below, are some of the views on 


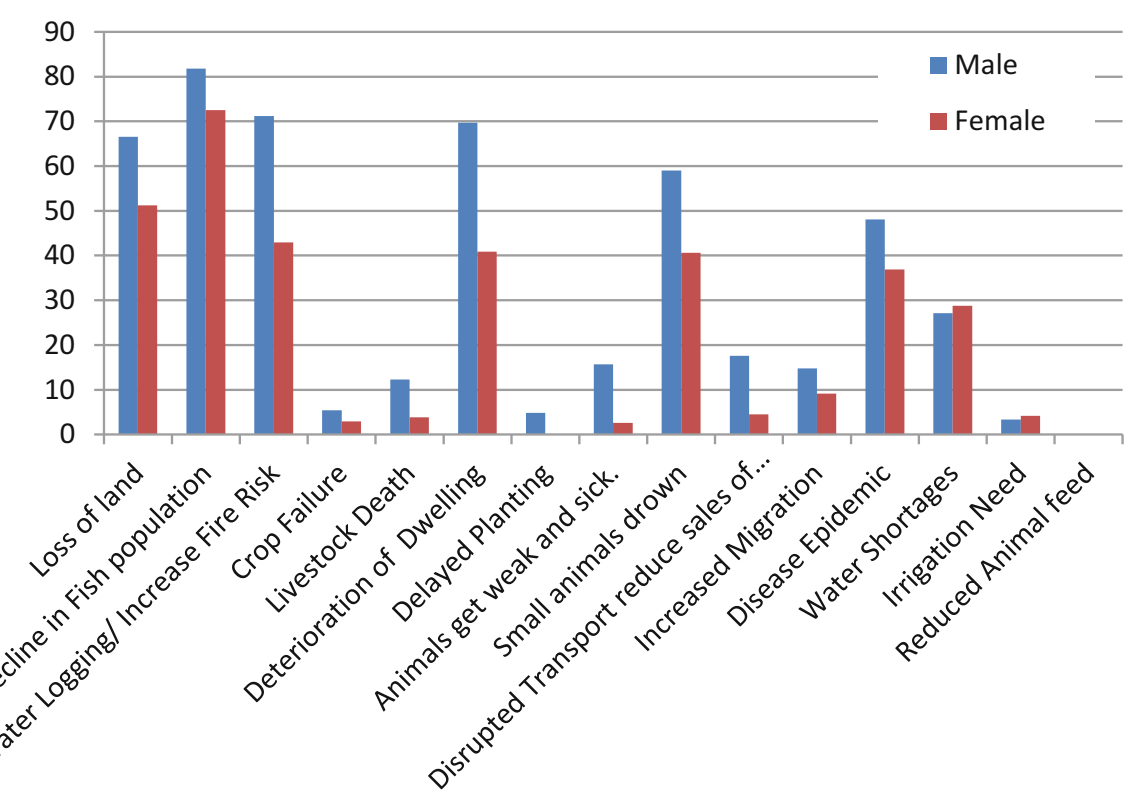

Fig. 2 Climate variability impact of livelihood security of aged men and women in Coastal Zone of Nigeria. (Source: Author's Fieldwork)

the impact of climate variability on their livelihood shared by aged men and women in Ilaje and Eseodo LGAs of Ondo:

Floodwater does not damage our land and properties in the past, it comes for some few hours and subsides back into the ocean but within the past few years it has been staying longer than a month, destroying lives and properties (Olayemi Elijah)

Floods are usually associated with heavy rainfall and ocean tides causing damages to our properties and drowning a number of people and animals. During Heavy rainfall, between June and July houses and land becomes waterlogged. The soil becomes saturated with water making it difficult for us to move from one place to another, disturbs our daily activities and causes retrogression in our socio-economic activities. (Thomas Ogunmola, Male, 67 years)

Flood has destroyed our crops, fishes and animals. Many of our animals die because of high salt level in the water. The flood water after mixing with sea water becomes polluted causing purging in human. The crude oil clogs the mat making plant (ifere), degrades the bamboo plantation (Opee), and also kills the aquatic animal, which serves as the major source of income to us (Osamoluwa Male, 71 years)

Socio-economic activities comes to a standstill during the flooding period, we women will not be able go to the market to trade. There is also high mortality rate in infants and the pregnant women during child labor because we lack health facilities. The only health centre available is too far from the community and there is no means of transportation most especially during the time of flooding (Adeola Ebijiimi Female 75 years)

In this year, from January to April, the rainfall was so scanty, resulting into heat wave, the weather became unbearable hot and the soil became too dry and too hot to grow crops on, any crop planted at this period dies off, but from May to July the rainfall became so intense which eventually resulted into flooding (Ebipatei Jonathan) 
We do encounter a lot of health and environmental hazard, these includes: rheumatism, purging, death of animals, degraded water and soil, erosion, drowning of our children and loss of life in general. (Obele)

Many of us aged suffer from rheumatism due to extreme cold weather while some of us have lost their lives due to drowning during flooding or tidal surge (Eyinmiieka Ayebogbon)

Figure 3 also indicated the impact of climate variability on livelihood security of the rural aged men and women in the Sudan Savannah Zone of Nigeria. The table revealed that $77.2 \%$ of the men and $89.3 \%$ of the women complained about loss of land. $85.3 \%$ of the men and $78.0 \%$ of the women complained of reduced pasture for their animals. $78.3 \%$ of the men and $71.4 \%$ of the women are worried because of water shortage and $67.7 \%$ men and $48.9 \%$ women felt the need for irrigation. Also, $90.6 \%$ of the men and $82.1 \%$ of the women lamented about crop failure and $77.2 \%$ men and $42.9 \%$ lamented about their dying livestock. From all these analysis, it is obvious that livelihood in Sudan Savannah Zone are affected by climate variability impact of drought and irregular rainfall. This is in line with Challinor et al. (2007) who explained that agricultural potential of the Sudan Savanna in West Africa is limited by insufficient water availability due to high rainfall variability and frequent droughts.

Our major occupation here is faming and rearing of livestock animals. Everything is okay. The only change is the issue of rain and drought. Before, rain starts around April and sometimes March. But now, that the climate has changed, it may start around June or July (Al Haruna)

We have a river here. Sometimes this river overflows and leads to flood. There is nothing we can do about such a situation because we do not have a choice. (Aisha Muhammad)

If you observe the route we followed here, the erosion has affected the bridge there. We have got about 30 bags of cement to do the bridge again. Even as we speak, if rain shouldfall, no one will be able to leave this town until the water level reduces (Kulu Galadima)

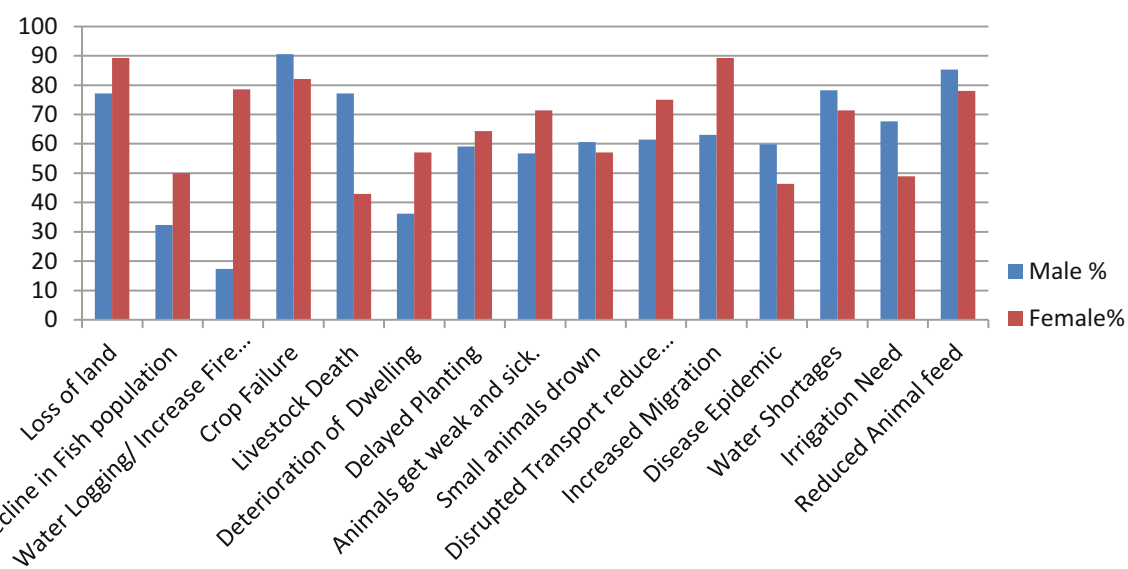

Fig. 3 Climate variability impact of livelihood security of aged men and women in Sudan Savannah Region of Nigeria. (Source: Author's Fieldwork) 

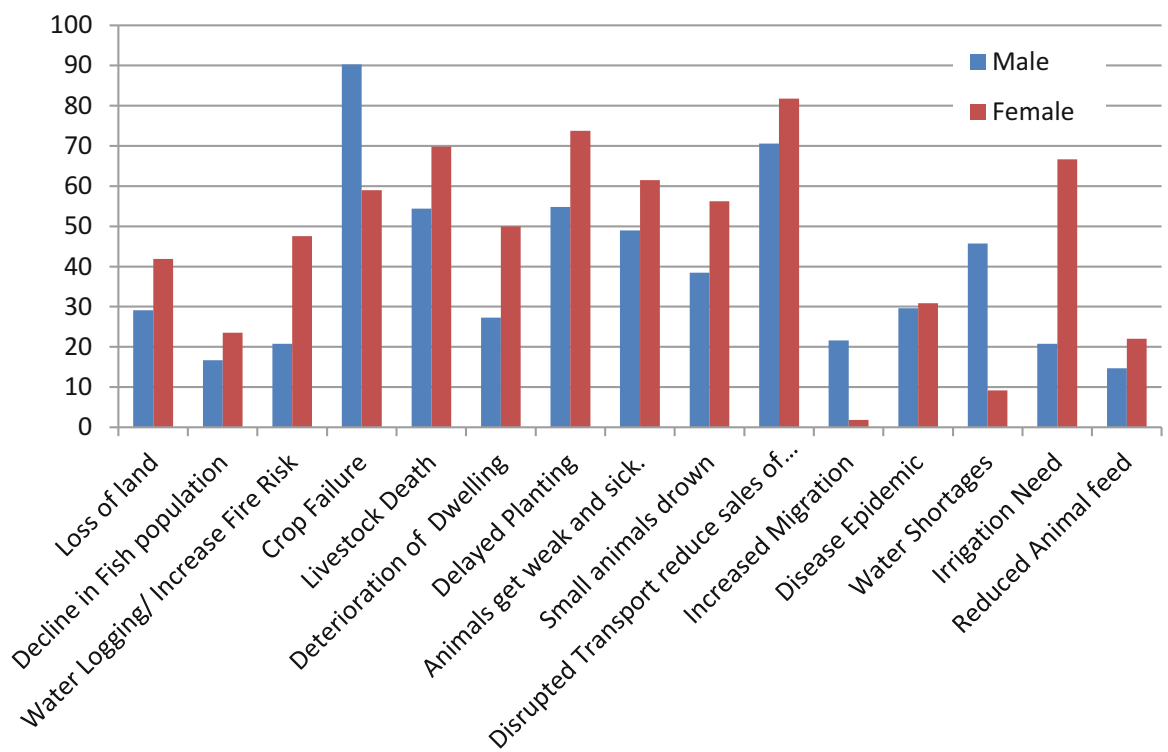

Fig. 4 Climate variability impact of livelihood security of aged men and women in Montane Region of Nigeria. (Source: Author's Fieldwork)

The drought usually affects our cultivated crops, in most cases we do re-planting after the drought might have destroyed the cultivation. So we plant immediately after the first rainfall that comes after a drought. For the flood, there is nothing we can do about it. What we do in most cases is to gather the redeemable crops and plant again after flood. (Amina Hakimi)

Figure 4 reveals the impact of climate variability on livelihood security of the rural aged men and women in the Montane Zone of Nigeria. The table revealed that $70.6 \%$ of men and $81.8 \%$ of women were not happy about disrupted transport reducing sales of goods; $58 \%$ of the men and $59 \%$ of the women complained of crop failure; $54.8 \%$ men and $73.8 \%$ talked about delayed planting; $49 \%$ of men and $61.5 \%$ of the women worried about their animals getting weak and sick while $54.4 \%$ men and $69.8 \%$ women complained about their dead livestock. This analysis was further corroborated with comments on the experiences of the aged men and women's climate variability impact on their livelihood security in the different selected villages of Plateau State of Montane Zone of Nigeria.

In this area we do not experience flood, but over there (neighboring village), all their houses and roads are filled with flood (Sunday Gaarus)

Lot of houses are usually affected. But for crops, only rice will do well in such condition. Last year we harvested plenty rice because rice needs a lot of water to grow. But crops like corn, guinea corn did not survive the weather. Millet also, for those farmers that had enough rain harvested it as well. We got millet here last year because we cultivated it around July ending to October ending, because it also can survive heavy rain. But crops like the ones I mentioned earlier, corn, and guinea corn will not survive it (Zababiya) 
In other places, they have not even had any rainfall at all this year. But we here are very lucky to have experienced several rainfall, though heavy. If we now start complaining about heavy rain, what should other places that have not experienced rain say? We do not know why God has decided to do it this way. So, to tell you I have an idea is unexplainable. Everything is God's doing (Mrs Ngyuk)

Generally, the impact and the experience of climate change on livelihood security of the aged men and women is peculiar to each ecological zone. This is because each ecological zone has its own peculiar characteristics. This is in line with CalloConcha et al. (2013) that says vulnerability to climate change impact is highly correlated with its geographical peculiarities. Therefore, the impact on the respondents is relative to the geographical characteristics.

\section{Conclusion}

Climate change is rapidly emerging as one of the most serious global problems affecting many sectors in the world especially rural livelihoods in agriculture, cattle rearing, crop farming, fishing, hunting, mining, tourism, and craft and weaving. It was found that the rural aged populations in Nigeria are highly vulnerable to climate change impact, especially in their livelihood security which was discovered to differ by region and by activity. This is in line with Garai (2014) which assessed climate change impact on the livelihoods of coastal people in the south-western part of Bangladesh revealed the elderly as part of the most at risk and vulnerable to climate change impact because of their inability to adapt to unfavorable environmental condition.

While some areas are generally more sensitive to climate change (Saarinen et al. 2012), some livelihoods and activities are more ecologically dependent and exposed to climate change impact. In consequence, the rural aged experience climate variability impact on their livelihood differently in different ecological zones, and their experience is based on the prevailing climate variability characteristics in each ecological zone.

In the Guinea and Sudan savannah zones, the prevailing climatic variability characteristics are drought, desertification, excessive heat and increased temperature, decline in rainfall, delayed onset of rainfall to mention a few. This is also in line with Ayanlade and Ojebisi (2019) which assessed herders' responses to climate variability and changes in the Guinea Savannah region of Nigeria. The study confirmed climate variability characteristics like excessive heat, reduced and delay onset of rainfall, prolonged dry spell, drought to mention a few in the area. Also in the Coastal zone the prevailing climatic variability characteristics are flooding, earlier onset of rain, erosion, increased frequency in storms. The impact on their livelihood in these zones is mainly associated with livestock death, lack of pastures for herds, scarcity of water, pest invasion, delayed planting crop failure, need for irrigation, water logging, drowning of small animals, human and animal illness. This implies that government planning and decision making related to climate change should take the views of the aged populations into consideration, especially for those rural areas affected most by climate change impact. 
Acknowledgments This research was supported by funding from Department for International Development (DfID), in the UK, under the program Climate Impacts Research Capacity and Leadership Enhancement (CIRCLE), implemented by the African Academy of Sciences and the Association of Commonwealth Universities.

\section{References}

Adger WN (2003) Social capital, collective action, and adaptation to climate change. Econ Geogr 79(4):387-404

Adger WN, Dessai S, Goulden M et al (2009) Are there social limits to adaptation to climate change? Clim Chang 93(3-4):335-354

Anele D (2012) A brief note on the condition of rural areas in0020Nigeria on January 29, 2012. The Vanguard Newspaper. https://www.vanguardngr.com/2012/01/a-brief-note-on-the-condition-ofrural-areas-in-nigeria/

Aniah P, Kaunza-Nu-Dem MK, Abindaw BA, Millar D (2016) Characterizing and explaining smallholder households views and understanding of climate change in the Bongo District of Ghana. Earth Sci 5(2):26-38

Ashwill M, Flora C, Flora J (2011) Building community resilience to climate change: testing the adaptation coalition framework in Latin America. The World Bank, Washington, DC

Ayanlade A, Ojebisi SM (2019) Climate change impacts on cattle production: analysis of cattle herders' climate variability/change adaptation strategies in Nigeria. Change Adaptat Socio Ecol Syst 5(1):12-23

Callo-Concha D, Gaiser T, Webber H, Tischbein B, Müller M, Ewert F (2013) Farming in the West African Sudan Savanna: insights in the context of climate change. Afr J Agric Res 8(38):46934705

Central Bank of Nigeria (2006) Statistical bulletin

Challinor A, Wheeler T, Garforth C, Crauford P, Kassam A (2007) Assessing the vulnerability of food crop systems in Africa to climate change. Clim Change 83:381-399

Collier P, Conway G, Venables T (2008) Climate change and Africa. Oxf Rev Econ Policy 24 (2):337-353

Deschenes O, Greenstone M (2012) The economic impacts of climate change: evidence from agricultural profits and random fluctuations of weather. Am Econ Rev 102(7):3761-3773

Douglas AC, Mills JE, Niang M, Stepchenkova S, Byun S, Ruffinia C et al (2008) Internet addiction: meta-synthesis of qualitative research for the decade 1996-2006. Comput Hum Behav 24:3027-3044

Eboh E (2009) Implications of climate change for economic growth and sustainable development in Nigeria Enugu forum policy paper 10. African Institute for Applied Economics, Enugu

Egbe C, Yaro MA, Okon AE, Bisong FE (2014) Rural people's perception to climate variability/ change in Cross River State Nigeria. J Sustain Dev 7(2):25

Fabiyi O, Oloukoi J (2013) Indigenous knowledge system and local adaptation strategies to flooding in coastal rural communities of Nigeria. J Indig Soc Dev 2(1):1-19

Garai J (2014) The impact of climate change on the livelihoods of coastal people in Bangladesh: a sociological study. In: Leal FW, Alves F, Caeiro S, Azeiteiro UM (eds) International perspectives on climate change: Latin America and beyond. Springer, Cham, pp 151-163

Government of Kenya (GoK) (2010) National climate change response strategy. Government Printer, Nairobi

Higgins PAT (2014) Climate change as a public and policy issue. Bull Am Meteor Soc 95:780-781

IPCC (2007) Impact, adaptation and vulnerability: contribution on working group 1 of the Intergovernmental Panel on Climate Change to the third Assessment Report of IPCC. Cambridge University Press, London

Keay RWJ (1949) An example of Sudan zone vegetation in Nigeria. J Ecol 37:335-364 
Kebede A, Hasen A, Negatu W (2011) A comparative analysis of vulnerability of pastoralists and agro-pastoralists to climate change: a case study in Yabello Woreda of Oromia Region, Ethiopia. Ethiop J Dev Res 33(1):61-95

Kueppers K (1998) Evaluation of the ligneous strata of the vegetation of the Zamfara reserve. I. In: Prospects of pastoralism in West Africa. Reihe I, vol 25. Tropeninstitut, Giessen, pp 41-47

McLeman R, Hunter LM (2010) Migration in the context of vulnerability and adaptation to climate change: insights from analogues. Wiley Interdiscip Rev Clim Chang 1(3):450-461

Mendelsohn R (2008) The impact of climate change on agriculture in developing countries. J Nat Resour Pol Res 1(1):5-19

O'Brien KL, Eriksen S, Nygaard LP, Schjolden A (2007) Why different interpretations of vulnerability matter in climate change discourses. Clim Pol 7(1):73-88

OECD (2001) OECD Annual Report

Ofoegbu C, Chirwa P, Francis J, Babalola F (2017) Assessing vulnerability of rural communities to climate change: a review of implications for forest-based livelihoods in South Africa. Int J Clim Change Strateg Manag 9(3):374-386

Okonkwo C, Demoz B, Sakai R, Ichoku C, Anarado C, Adegoke J, Amadou A, Abdullah SI (2015) Combined effect of El Niño southern oscillation and Atlantic multi decadal oscillation on Lake Chad level variability. Cogent Geosci 1:1117829

Popoola K, Ajayi S (2019) Rural Ageds' awareness and perception of climate variability in Kanke and Riyom local government areas of Plateau State, Nigeria. Arch Current Res Int 16(1):1-13. https://doi.org/10.9734/ACRI/2019/46174

Saarinen J, Hambira WL, Atlhopheng J, Manwa H (2012) Tourism industry reaction to climate change in Kgalagadi South District, Botswana. Dev South Afr 29(2):273-285

Sarr B (2012) Present and future climate change in the semi-arid region of West Africa: a crucial input for practical adaptation in agriculture. Atmos Sci Lett 13(2):108-112

Scholze M, Knorr W, Arnel NW, Prentice IC (2006) A climate-change risk analysis for world ecosystems. Proc Natl Acad Sci USA 103(35):116-120

Thornton PK, Ericksen PJ, Herrero M, Challinor AJ (2014) Climate variability and vulnerability to climate change: a review. Glob Chang Biol

Ubisi NR, Mafongoya PL, Kolanisi U, Jiri O (2017) Smallholder farmer's perceived effects of climate change on crop production and household livelihoods in rural Limpopo province, South Africa. Change Adapt Socioecol Syst 3:27-38

World Bank (2008) Agriculture for development. World development report. The World Bank, Washington, DC

World Bank Group (2017) The world bank annual report

Zeleke MT, Aberra Y (2014) Determinants of the adoption of land management strategies against climate change in Northwest Ethiopia. ERJSSH 1(1):93-118

Open Access This chapter is licensed under the terms of the Creative Commons Attribution 4.0 International License (http://creativecommons.org/licenses/by/4.0/), which permits use, sharing, adaptation, distribution and reproduction in any medium or format, as long as you give appropriate credit to the original author(s) and the source, provide a link to the Creative Commons license and indicate if changes were made.

The images or other third party material in this chapter are included in the chapter's Creative Commons license, unless indicated otherwise in a credit line to the material. If material is not included in the chapter's Creative Commons license and your intended use is not permitted by statutory regulation or exceeds the permitted use, you will need to obtain permission directly from the copyright holder.

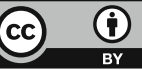

